\title{
ПОЗИЦІОНУВАННЯ ЛОГІСТИЧНОГО ПЦДПРИЕМСТВА НА РИНКУ МЕБЛІВ ЗА УМОВ МІЖНАРОДНОГО СПІВРОБІТНИЦТВА
}

\author{
DOI: 10.32620/cher.2019.2.02
}

Постановка проблеми. У науковій статті досліджено питання щодо доцільності виявлення критеріїв оцінки міжнародних логістичних транспортно-експедиторських організацій в умовах стрімкого розвитку української меблевої галузі. Метою статmі є формування критеріїв оцінки міжнародних логістичних транспортно-експедиторських фірм з огляду на існуючу перспективність в розвитку меблевої галузі України та їі визначену орієнтацію на зовнішньо-економічну діяльність. Об 'єкm дослідження - логістичне підприємство на ринку меблів України в ланцюжку міжнародного співробітництва та взаємодії. Методи, використані в досліджені. Методологічне підгрунтя дослідження становить система наукових методів застосованих у комплексі для досягнення мети та вирішення поставлених завдань. Діалектичний метод дав можливість обгрунтувати причино-наслідкові зв'язки у процесі позиціонування логістичного підприємства на ринку меблів України. Історичний метод застосовано при вивченні історичного досвіду хронології подій і фактів на ринку меблів України. Для одерження дослідницьких висновків використано також загальнонаукові системний та логічний методи. Емпіричною базою стали міжнародні конвенції двосторонні договори, законодавчі акти України, довідкова література. Гіпотеза дослідження. Немає однозначного погляду на проблему формування єдиного набору критеріїв оцінки міжнародних транспортно-логістичних посередників, тому розгляд та дослідження особливостей оцінки таких елементів ланцюга міжнародних поставок є відкритим й необхідним для покращення діяльності українських меблевих підприємств. Buклад основного матеріалу. Розглянуто фактори, які призвели до активізації ЗЕД на меблевих підприємствах. Встановлено роль та основні переваги використання міжнародних транспортноекспедиторських посередників. Виявлено основні недоліки в наборах критеріїв в існуючих методиках оцінки транспортно-логістичних організацій. Оригінальність та практичне значення дослідження полягає у запропонуванні критеріїв оцінки в процесі вибору потенційних міжнародних логістичних транспортно-експедиторських партнерів, яких доцільно дотримуватися меблевим підприємствам. Обгрунтовано доцільність використання запропонованих критеріїв 3 метою облегшення процесу вибору потенційних транспортно-логістичних партнерів для ведення бізнесу в меблевій галузі. Висновки дослідження. Направленість українського ринку на «завоювання» іноземних ринків, зумовлює необхідність вдосконалення існуючих методів оцінки рівня якості надання міжнародних транспортних операцій, що допомагають менеджменту логістичних підприємств і клієнтам оптимально оцінити ступінь ефективності послуг, рівень задоволення потреб клієнтів, визначити слабкі і сильні місця в рамках даної діяльності, і скорегувати відповідно до цього систему менеджменту і впровадити інновації.

Ключові слова:

економічне зростання, активізація, меблева промисловість, митна логістика, транспортнологістичний оператор.

${ }^{1}$ Кракос Юлія Борисівна, канд. екон. наук, доцент кафедри «Фінанси», Національний аерокосмічний університет ім. М.Є. Жуковського «Харківський авіаційний інститут», м. Харків, Україна.

Krakos Julia, Ph.D. in Economic, Associate Professor of Finances Department National Aerospace University «Kharkiv Aviation Institute», Kharkiv, Ukraine.

ORCID ID: 0000-0001-8058-6336

e-mail: july.krakos@gmail.com

2 Приходько Аліна Олександрівна, магістрант спеціальності «Фінанси, банківська справа та страхування», Національний аерокосмічний університет ім. М.С. Жуковського «Харківський авіаційний інститут», м. Харків, Україна.

Prikhodko Alina, Master's degree of Finance, Banking and Insurance Specialty National Aerospace University «Kharkiv Aviation Institute», Kharkiv, Ukraine.

ORCID ID: 0000-0003-1109-0542

e-mail: aprikhodko96@gmail.com 


\section{LOCALIZATION OF LOGISTIC ENTERPRISES ON THE FURNITURE MARKET UNDER THE CONDITIONS OF INTERNATIONAL COOPERATION}

Formulation of the problem. The article deals with the issue of the expediency of identifying the criteria for the evaluation of international logistics freight forwarding organizations in the conditions of the rapid development of the Ukrainian furniture industry. The purpose of the research is to establish criteria for the evaluation of international logistics freight forwarding firms in view of the existing prospects in the development of the furniture industry in Ukraine and its definite orientation towards foreign economic activity. The object of the research is a logistics enterprise on the Ukrainian furniture market in a chain of international cooperation and interaction. The methods used in the research. The methodological basis for the study is the system of scientific methods used in the complex to achieve the goal and solve the tasks. The dialectical method made it possible to substantiate the causal relationships in the process of positioning a logistics company in the Ukrainian furniture market. The historical method has been used in the study of historical experience of the chronology of events and facts on the Ukrainian furniture market. In order to obtain research findings, also general scientific system and logical methods are used. The international conventions of bilateral treaties, legislative acts of Ukraine, reference books became the empirical base. The hypothesis of research. There is no unambiguous view on the problem of forming a single set of criteria for the assessment of international transport logistics intermediaries, therefore consideration and study of the peculiarities of the assessment of such elements of the international supply chain is open and necessary for the improvement of the activity of Ukrainian furniture enterprises. The statement of basic material. The factors that led to the activation of foreign economic activity at furniture enterprises were considered. The role and main advantages of using international forwarding intermediaries are established. The main shortcomings in the criteria sets in the existing methods of estimation of transport and logistics organizations are revealed. The originality and practical significance of the research is to offer evaluation criteria in the process of selecting potential international logistics freight forwarding partners, which should be observed by furniture companies. The expediency of using the proposed criteria was substantiated in order to facilitate the process of selecting potential transport and logistics partners for doing business in the furniture industry. Conclusions of the research. The direction of the Ukrainian market for the "conquest" of foreign markets, necessitates the improvement of existing methods for assessing the level of quality of international transport operations, helping management of logistics companies and clients to optimally assess the degree of service effectiveness, the level of satisfaction of customers, identify the weak and strong points within the framework of this activity, and adjust in accordance with this management system and innovate.

Key words:

economic growth, activation, furniture industry, customs logistics, transport and logistics operator.

\section{ПОЗИЦИОНИРОВАНИЕ ЛОГИСТИЧЕСКОГО ПРЕДПРИЯТИЯ НА РЫНКЕ МЕБЕЛИ В УСЛОВИЯХ МЕЖДУНАРОДНОГО СОТРУДНИЧЕСТВА}

Постановка проблемы. В научной статье исследован вопрос о целесообразности выявлен ния критериев оценки международных логистических транспортно-экспедиторских организаций в условах стремительного развития украинского мебельной отрасли. Целью статьи является формирование критериев оценки международных логистических транспортно-экспедиторских фирм учитывая существующую пер-спективнисть в развитии мебельной отрасли Украины и ее определенную ориентацию на внешнеэкономическую деятельность. Объект исследования - логистическое предприятие на рынке мебели Украины в цепочке международного сотрудничества и взаимодействия. Метоdbl, использованные в исследовании. Методологическое основание исследования составляет система научных методов, применяемых в комплексе для достижения цели и решения поставленных задач. Диалектический метод дал возможность обосновать причинно-следственные связи в процессе позиционирования логистического предприятия на рынке мебели Украины. Исторический метод применен при изучении историкоческого опыта хронологии событий и фактов на рынке мебели Украины. Для получения исследовательских выводов использовано также общенаучные, системный и логический методы. Эмпирической базой стали международные конвенции двусторонние договоры, законодательные акты Украины, справочная литература. Гипотеза исследования. Нет однозначного взгляда на проблему формирования единого набора критериев оценки международных транспортнологистических посредников, поэтому рассмотрение и исследование особенностей оценки таких элементов цепи международных поставок является открытым и необходимым для улучшения деятельности украинских мебельных предприятий. Изложение основного материала. Рассмотрены факторы, которые привели к активизации ВЭД на мебельных предприятиях. Установлена роль и основные 
преимущества использования международных транспортно-экспедиторских посредников. Выявлены основные недостатки в наборах критериев в существующих методики оценки транспортнологистических организаций. Оригинальность и практическое значение исследования заключается в предложении критериев оценки в процессе выбора потенциальных международных логистических транспортно-экспедиторских партнеров, которых целесообразно придерживаться мебельным предприятиям. Обоснована целесообразность использования предложенных критериев для облегчения процесса выбора потенциальных транспортно-логистических партнеров для ведения бизнеса в мебельной отрасли. Выводы исследования. Направленность украинского рынка на «завоевание» иностранных рынков, вызывает необходимость совершенствования существующих методов оценки уровня качества предоставления международных транспортных операций, помогают менеджмента логистических предприятий и клиентам оптимально оценить степень эффективности услуг, уровень удовлетворения потребностей клиентов, определить слабые и сильные места в рамках данной деятельности, и скорое соответствии с этим систему менеджмента и внедрить инновации.

\section{Ключевые слова:}

экономический рост, активизация, мебельная промышленность, таможенная логистика, транспортно-логистический оператор.

Постановка проблеми. Характерною особливістю сучасного періоду розвитку меблевого ринку України є зростання імпорту іноземних меблів в Україну, зростання експорту меблів українського виробництва, а також активний приплив в меблеву та деревообробну галузь іноземного капіталу. Такі тенденції обумовлюють зростання інтересу до невід'ємних складових цих процесів, а саме до транспортної логістики на самому підприємстві та до використання транспортноекспедиторських фірм в процесі ЗЕД.

Кожне підприємство в процесі своєї фінансово-господарської діяльності зіштовхується 3 проблемою вибору надійних партнерів, а відсутність єдиної методики їх оцінки, яка б підходила до всіх сфер діяльності фірм (зокрема меблевій галузі), обгрунтовує необхідність формування критеріїв для вибору та оцінки потенційних партнерів (в даному випадку - транспортно-експедиторських фірм) меблевих підприємств.

Аналіз останніх джерел та публікацій. Вивчення наукової літератури дало змогу встановити, що, незважаючи на достатньо високий рівень існуючих проблем оцінки транспортно-логістичних організацій, питання їх оцінки висвітлюється досить рідко. В даній статті автори опираються на результати дослідницької, фахової роботи таких науковців: С. В. Крикавський [4], Д. В. Стаханов [5], I. В. Міщенко [9], В.І Лямець та А.Д. Тевяшев [6] та О.М. Горяїнов [15].

Немає однозначного погляду на проблему формування єдиного набору критеріїв оцінки міжнародних транспортнологістичних посередників, тому розгляд та дослідження особливостей оцінки таких еле- ментів ланцюга міжнародних поставок є відкритим й необхідним для покращення діяльності українських меблевих підприємств.

Метою статті $\epsilon$ дослідження ролі міжнародних логістичних транспортноекспедиторських фірм з огляду на теперішню перспективність в розвитку меблевої галузі України та їі визначену орієнтацію на ЗЕД.

Для досягнення цієї мети були поставлені наступні завдання: визначення сучасного стану меблевої промисловості України; визначення основних факторів впливу на розвиток меблевої галузі України; формування ролі міжнародних логістичних транспортноекспедиторських фірм у ЗЕД меблевих підприємств; виявлення недоліків та необхідності запровадження відмінного від існуючого набору критеріїв для оцінки міжнародних логістичних транспортно-експедиторських фірм як партнерів меблевих підприємств; ідентифікація переваг від запровадження сформованих критеріїв оцінки.

Виклад основного матеріалу дослідження. Підсумки розвитку економіки України за останні роки свідчать про продовження позитивних економічних тенденцій, які формують основу для подальшого якісного економічного зростання країни. Так, впродовж 2010-2013 років, спостерігалося стабільне зростання показників реального валового внутрішнього продукту (ВВП) в цінах попередніх років. Свій негативний відбиток у вигляді спаду в 2014-2015 рр. при розгляді динаміки росту показників валового внутрішнього продукту країни за 2010-2018 роки, залишила економічна й політична криза в країні (рис. 1). 


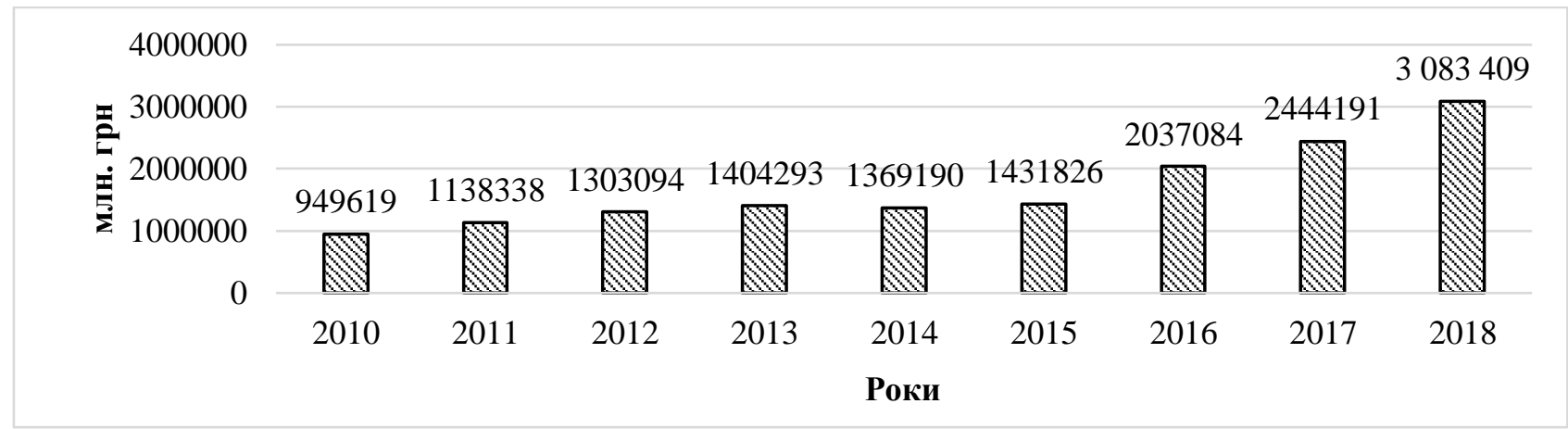

Рис. 1. ВВП України за 2010-2018 роки, млн. грн

Джерело: узагальнено авторами на підставі [1]

Як свідчить МЕРТ [11] основними факторами зростання були переважно внутрішні чинники - інвестиційний та споживчий попит на вітчизняну продукцію. Інтенсивний розвиток інвестиційної сфери став одним з основних джерел економічного зростання, який підтримувався покращенням фінансового стану підприємств та розширенням можливостей їх фінансування.

Зростання показників виробництва в останні роки, демонструють різні сфери про-

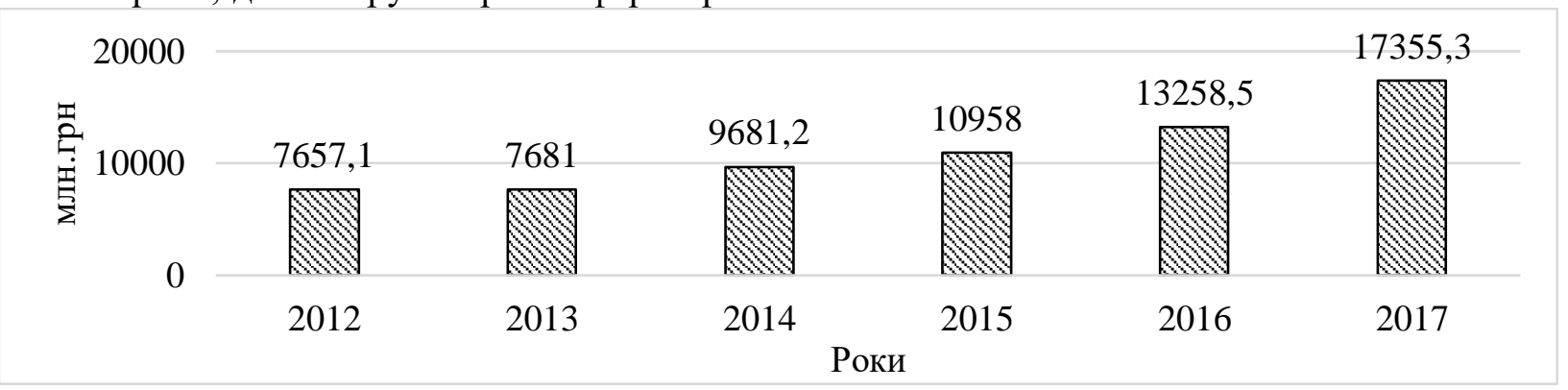

Рис. 2. Обсяги виробництва меблів в Україні за 2012-2017 роки, млн. грн Джерело: узагальнено авторами на підставі [1]

Така динаміка беззаперечно демонструє прогрес розвитку меблевої галузі України, але потрібно розуміти, що лягло в основу такого стрімкого, не властивого українській продукції підйому. Через зростання курсу долара багато хто був змушений відмовитися від імпортних меблів, віддавши перевагу вітчизняному виробнику. Меблеві компанії в свою чергу, щоб відповідати вимогам покупців і залишатися конкурентними в кризу, стрімкими темпами стали модернізувати застаріле обладнання, розширювати асортимент продукції і освоювати нові технології та тренди.

Сьогодні в Україні налічується понад 3 тисячі компаній-виробників меблів. Серед них: великі меблеві фабрики, що виготовляють меблі серійно, середні підприємства, що мисловості України, серед яких харчова промисловість, машинобудування, торгівля, виробництво будматеріалів та транспортна галузь, зокрема деревообробна та меблева промисловість.

Наразі, ситуація в вітчизняній меблевій галузі стабільно прогресуюча. Загальні обсяги виробництва меблів в Україні за 2012-2017 роки постійно зростають (рис. 2).

працюють за індивідуальними замовленнями i дрібні, серед яких близько $30 \%$ - мікропідприємства. Великі виробники мають більш якісне обладнання, що забезпечує їм великі, в порівнянні з середніми і малими підприємствами, обсяги виробництва. При цьому великі виробники мають меншу виробничої гнучкістю і не можуть швидко реагувати на зміну смаків, стилів і дизайнерських трендів. У меншій мірі такі виробники можуть задовольняти індивідуальні запити, що з успіхом здійснюють середні і малі суб'єкти господарювання меблевої галузі [5].

Меблі українського виробництва відрізняються від інших товарів на ринку, оскільки вони набагато дешевші за імпортні, що пояснюється меншими витратами на виробництво, доставку і низькою ціною матеріалів, 
в разі використання вітчизняної сировини, а також оподаткуванням.

Меблі - продукт тривалого використання, тому іiі випуск характеризується рядом особливостей, на які впливають різні чинники (табл. 1).

Особливості виготовлення меблів та чинники впливу

\begin{tabular}{|c|c|}
\hline $\begin{array}{c}\text { Особливості виготовлення } \\
\text { меблів }\end{array}$ & Чинники впливу \\
\hline Складний цикл виробництва & $\begin{array}{l}\text { Основні: } \\
\text { - технологічні (перш за все розвиток технологій задіяних в } \\
\text { виробництві); } \\
\text { - організаційні (кваліфікація персоналу та стан робочих } \\
\text { приміщень); } \\
\text { - економічні (зміни цін на сировину та матеріали; наявність } \\
\text { фінансових і кредитних ресурсів). }\end{array}$ \\
\hline $\begin{array}{l}\text { Тривалий період виведення на } \\
\text { ринок нових моделей }\end{array}$ & $\begin{array}{l}\text { - складність пошуку нових ринків збуту (бар'єри входу на } \\
\text { європейські ринки); } \\
\text { - особливості державного регулювання (квоти, регулювання } \\
\text { експорту). }\end{array}$ \\
\hline Високі вимоги до якості & $\begin{array}{l}\text { До вітчизняних стандартів якості додаються стандарти то- } \\
\text { варів ЕС, через необхідність дотримання останніх при ба- } \\
\text { жанні освоєння європейських ринків. }\end{array}$ \\
\hline $\begin{array}{l}\text { Наявність гарантійного та після- } \\
\text { гарантійного обслуговування }\end{array}$ & $\begin{array}{l}\text { - фінансова стабільність компанії; } \\
\text { - розмір підприємства та розвиненість торгової мережі). }\end{array}$ \\
\hline $\begin{array}{l}\text { Конкуренція на ринку нових і } \\
\text { бувших в потребі товарів }\end{array}$ & Фактичний тривалий фізичний знос. \\
\hline $\begin{array}{l}\text { Тривалий період вибору і здійс- } \\
\text { нення покупки покупцями }\end{array}$ & $\begin{array}{l}\text { - структура витрат споживачів; } \\
\text { - співвідношення ціни і якості асортименту }\end{array}$ \\
\hline
\end{tabular}

\section{Джерело: узагальнено авторами на підставі [12]}

3 огляду на складену ситуацію на меблевому ринку можна сформулювати ряд основних проблем вітчизняного меблевого ринку (рис. 1).

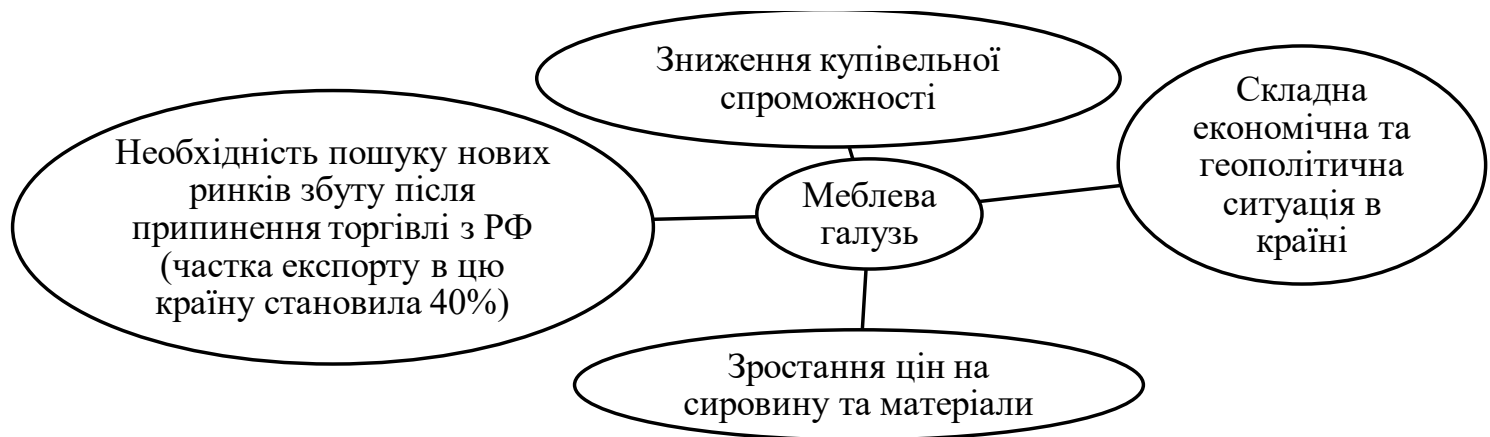

Рис. 1. Основні проблеми меблевої галузі України Джерело: узагальнено авторами на підставі [12] 


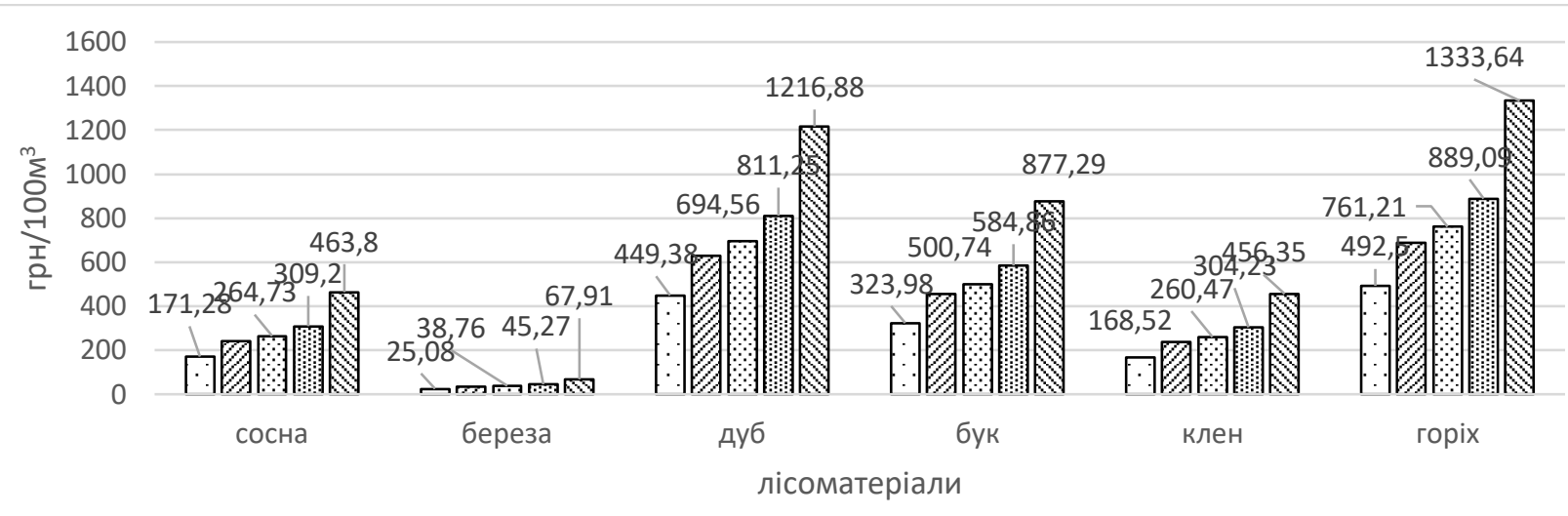

口2015 曰2016 2017 团2018 ه2019

Рис. 3. Динаміка цін на лісоматеріали в Україні за 2015-2019 роки, грн/100 м³ Джерело: розроблено авторами на підставі [2]

Зокрема, ціни на лісоматеріали впродовж довгого періоду залишалися майже незмінними, суттєві зміни припали саме на період пожвавлення мебельної промисловості в останні роки (рис. 3).

Основною сировиною для виготовлення меблів $\epsilon$ деревина та пиломатеріали. Україна щорічно заготовляє понад 20 млн. м3 деревини і пиломатеріалів для виробництва меблів практично повністю українського виробництва. Виключення складають специфічні породи дерев, які не ростуть в Україні (наприклад, червоне дерево) [7].

У листопаді 2015 року в Україні був заборонений експорт всіх порід деревини, за винятком сосни, а в грудні 2017 року цю заборону також було поширено й на сосну. Україна експортує кругляк та інші лісоматеріали у країни Балтії та Свропи, забезпечуючи їхню промисловість дешевою сировиною. Але більшість лісоматеріалів споживається все ж таки на внутрішньому ринку. Метою заборони було зробити деревину менш дефіцитною та дорогою за рахунок зменшення обсягів експорту, особливо високоякісної деревини, для підтримки розвитку місцевої галузі та створення більшої доданої вартості в Україні. Наслідки цієї заборони є не дуже позитивними. Власники лісу (в основному держлісгоспи) просто зменшили заготівлю або почали експортувати певні обсяги нелегально. «Сіра» рубка та незаконний експорт є дуже поширеними, і заборона експорту лісу зупинила їх лише частково [8].

Показники імпорту та експорту меблів в Україні значно змінювалися в останні роки під впливом змін в економіці і зміні політичного курсу країни (рис. 4).

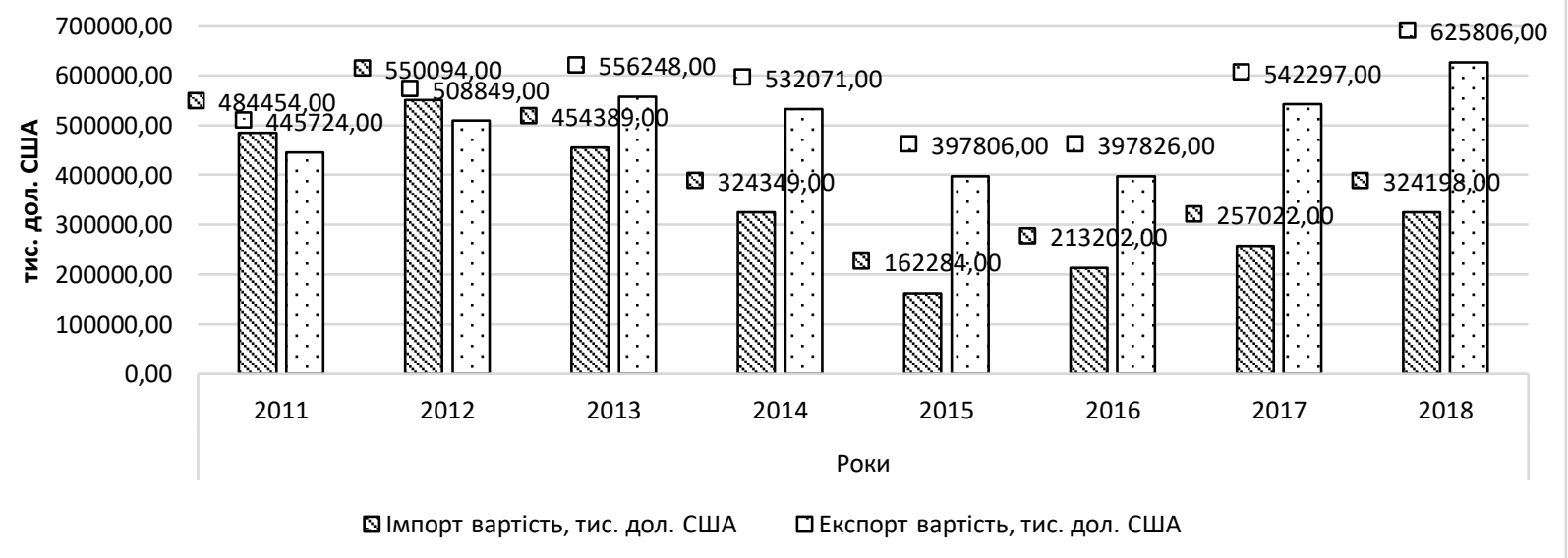

Рис. 4. Показники імпорту та експорту меблів України за 2011-2018 роки, тис. дол. США Джерело: узагальнено авторами на підставі [2]

Зростання експорту та імпорту в цій галузі, породжує інтерес до невід'ємної части- ни цих процесів, а саме до митної логістики. Визначення поняття «митна логістика» зу- 
стрічається в роботах Смирнова I. Г. та Стаханова Д. В. [4,5]. Автори даної роботи дали цьому терміну наступне визначення: митна логістика - це комплекс дій, орієнтованих на міжнародну доставку вантажів і оформлення необхідних для цього документів. Логістичні послуги $\epsilon$ важливими складниками ринкової системи господарювання, адже завдяки ним, забезпечується налагодження, безперебійний рух матеріалів, ресурсів і готової продукції від виробника до споживача.

За допомогою митної логістики, підприємства, діяльність яких пов'язана з експортом чи імпортом готових товарів (послуг), або сировини для виробництва, мають можливість оптимізувати ці процеси, зробивши їх менш витратними та швидкими, адже спира- ючись на думку експертів компанії «ZAMMLER» витрати на логістику - це одна зі складових формування собівартості виробленої продукції, витратна частина, яка, в підсумку, впливає на ціноутворення [10].

Логістична функція митної справи у свою чергу охоплює дві складові, а саме логістизацію процесу митної переробки вантажів (аналіз митно-логістичних потоків, пов'язаних 3 перетином митного кордону України зовнішньоторговельними потоками; стягнення відповідних митних зборів і платежів), та митну діяльність транспортнологістичних компаній (як іноземних, що діють в Україні, так і українських) [9].

Складові митної логістики зображені на рис. 5.

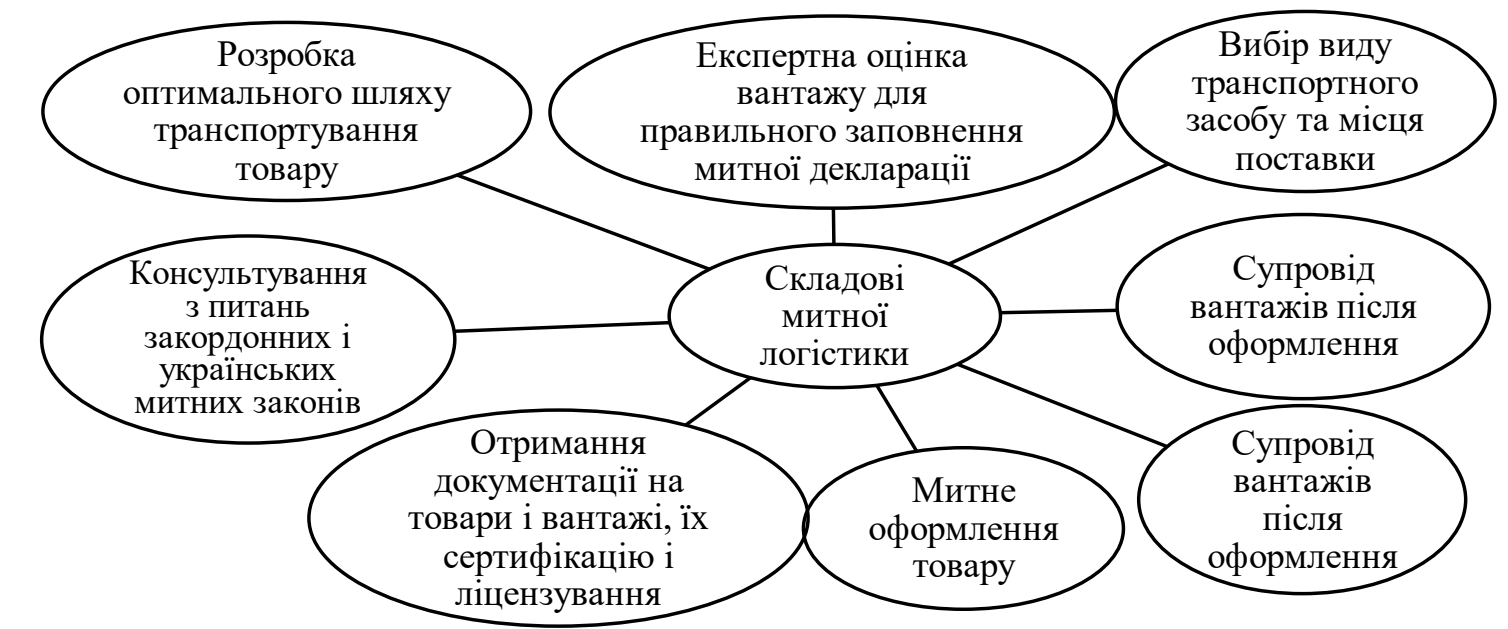

Рис. 5. Складові митної логістики

Джерело: розроблено авторами

При транспортуванні меблів, важливим рішенням для підприємства стає вибір транспортного засобу. Як показує практика, незалежно від розміру підприємств, автомобільний транспорт в вирішенні цього питання на думку авторів знаходиться майже поза конкуренцією. Це можна пояснити рядом переваг даного виду транспорту, а саме:

- високою доступністю;

- можливістю доставки вантажу «від дверей до дверей»;

- високою гнучкістю та маневреністю;

- високою швидкістю доставки;

- можливістю використовувати різні маршрути;

- можливістю відправки вантажу невеликими партіями;

- широкою можливостю вибору підходящого перевізника.

Такий вибір, знаходить своє підтвердження в отриманих даних Державної служ- би статистики України, щодо обсягів перевезених вантажів України, залежно від вибору виду транспорту (табл. 2).

«Відчутна» конкуренція спостерігається лише зі сторони залізничного виду транспорту, що пояснюється його перевагою при перевезенні не готової продукції, а сировини та матеріалів для виробництва, що вимагають високу вантажопідйомність транспортного засобу.

Згідно $з$ даними Державної служби статистики України у 2018 році загальний об'єм перевезення меблів автомобільним транспортом зріс у порівнянні з 2017 роком і склав 764,16 тисяч тон (у 2017 році - 568,60 тисяч тон (з нього в міжнародному сполученні за 2018 рік об'єм перевезених меблів склав 138,58 тисяч тон, а в 2017 році - 134,26 тисяч тон). 
Т а бли ц я 2

Обсяг перевезених вантажів за видами транспорту за 2011-2018 роки, тис. грн

\begin{tabular}{|c|c|c|c|c|}
\hline \multirow{2}{*}{ Роки } & \multicolumn{4}{|c|}{ Види транспорту } \\
\cline { 2 - 5 } & Залізничний & Морський & Автомобільний & Авіаційний \\
\hline 2011 & 469308,10 & 4145,60 & 1252390,30 & 92,10 \\
\hline 2012 & 457454,50 & 3457,50 & 1259697,70 & 122,60 \\
\hline 2013 & 443601,50 & 3428,10 & 1260767,50 & 99,20 \\
\hline 2014 & 386276,50 & 2805,30 & 1131312,70 & 78,60 \\
\hline 2015 & 349994,80 & 3291,60 & 1020604,00 & 69,10 \\
\hline 2016 & 343433,50 & 3032,50 & 1085663,40 & 74,30 \\
\hline 2017 & 339550,50 & 2253,10 & 1121673,60 & 82,80 \\
\hline 2018 & 322342,10 & 1892,00 & 1205530,80 & 99,10 \\
\hline
\end{tabular}

Джерело: узагальнено авторами на підставі [1]

У рамках організації ланцюжка міжнародних поставок неминуче виникає питання доцільності організації власного центру логістичних послуг на підприємстві. Але власна логістика має ряд недоліків (рис. 6) у порів- нянні 3 використанням послуг сторонніх професійних транспортних експедиторів як в частині прямих витрат у розрахунку на одиницю продукції, так і наданих можливостей i наявних ризиків.

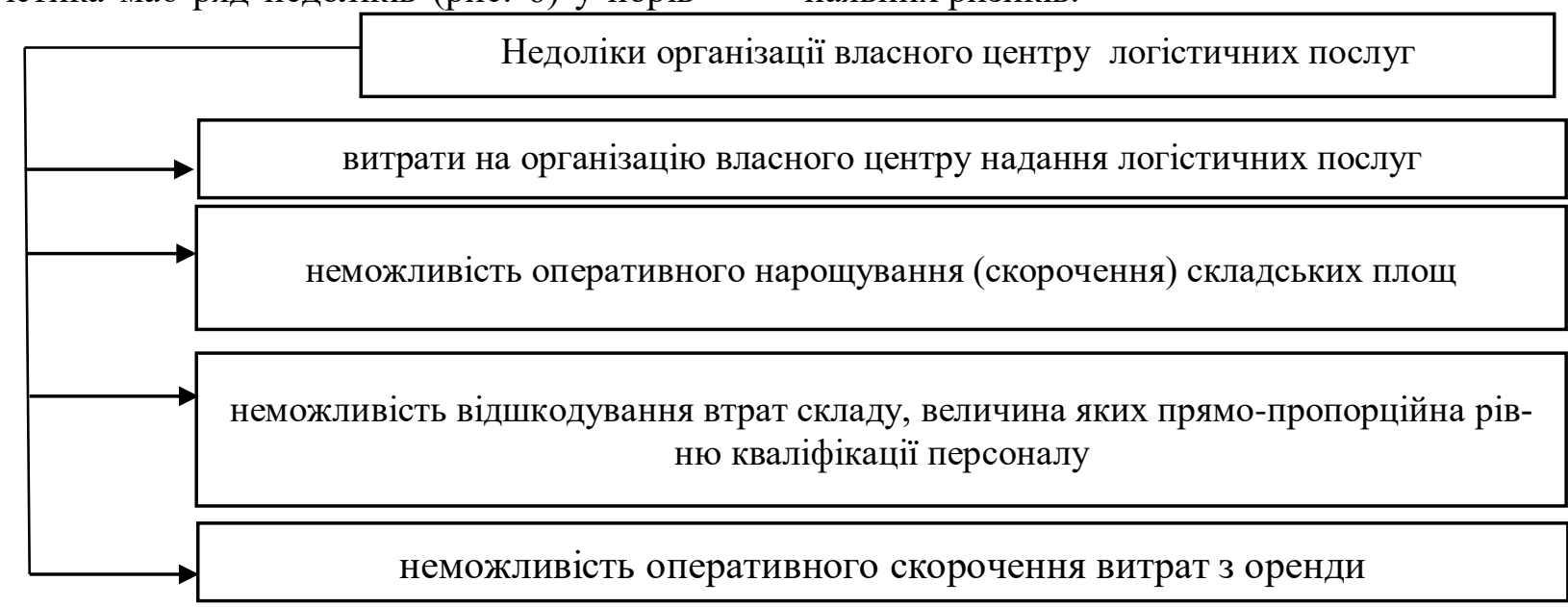

Рис. 6. Головні недоліки налагодження власного центру логістичних послуг Джерело: узагальнено авторами на підставі [12]

Передача транспортної логістики професійному логістичному оператору дає можливість підприємствам, по-перше, сфокусуватися на основних виробничих процесах, а подруге, мінімізувати всі можливі ризики помилок пов'язаних 3 транспортною логістикою та процесом складської обробки товарів.

Міжнародні транспортноекспедиторські фірми своїми функціями охоплюють всі процеси перевезення вантажів: від визначення маршруту транспортування до оформлення необхідної документації (звіти, митна документація та ін.).

Міжнародні експедитори забезпечують переміщення товарів від місця їх виробництва до країни розташування споживача. Так, якщо підприємство вирішило «покласти» всі питання 3 перевезення, разом 3 усіма нюансами що стосуються даного процесу, на транспортного експедитора, вирішальним завданням для нього (підприємства), стане вибір партнера (партнерів) на ринку транспортноекспедиційного забезпечення розподілу товарів.

Аналіз існуючих методик оцінки логістичних транспортно-експедиторських фірм в загальному вигляді дозволив виділити критеpiï їх оцінки. Отже, при виборі логістичного оператора в багатьох методиках основними критеріями оцінки звичайно виступають зведені критерії на основі експертних оцінок О. М. Горяїнова [13]:

- релейні - наявність сертифікату; 
- кількісні - надійність, тариф, загальний час (можливість відхилення від планової тривалості перевезення, \%), фінансова стабільність;

- якісні - частота сервісу, збереженість, кваліфікація персоналу, готовність до переговорів.

При виборі перевізника в першу чергу перевіряються релейні показники. Серед перевізників 3 подальшого розгляду виключаються ті, що мають значення релейного показника «ні». Значення інтегральної оцінки встановлюють на основі значень якісних i кількісних оцінок з урахуванням вагових коефіцієнтів [13].

Використання таких критеріїв оцінки можливе тільки за умови, якщо транспортні засоби на кожному 3 потенційних (тобто міжнародних транспортно-логістичних організацій), мають однакові характеристики, що на практиці відбувається доволі рідко.

Розглянуті «головні критерії» оцінки логістичних посередників не охоплюють такі фактори впливу на рішення підприємства як:

- наявність додаткового обладнання обробки вантажів;

- наявність додаткових послуг комплектації і складування вантажу;

- гнучкість тарифних схем;

- пряма взаємодія з вантажоперевізниками і терміналами;

- наявність розвиненої мережі зв'язків;

- контроль руху, інформування.

Доповнень критеріїв оцінки потребують і кількісні показники вищезазначених методик. Обсяги перевезень, що виконуються логістичною компанією, кількість і термін експлуатації транспорту, загальні показники діяльності компанії в даних методиках нажаль не знаходять свого відображення.

Застосування вищезазначених критеріїв оцінки міжнародних логістичних транспортно-експедиторських фірм, значно розширить уявлення про потенційного партнера для ведення бізнесу.

Особливе місце серед зазначених «допоміжних критеріїв» належить релейним та якісним показникам, адже по-перше, пошук потенційних «транспортних партнерів» починається 3 огляду на власні вже складені вимоги до майбутніх партнерів, по-друге значимість кількісних показників не має сенсу при наявності не відповідності вимогам замовника перших.
На сьогодні багато українських транспортно-логістичних фірм зарекомендувало себе як надійні перевізники, що спеціалізуються на міжнародних перевезеннях, але більшість 3 них працює лише в одному напряму, а саме в транспортній логістиці. Діяльність таких фірм потребує розширення на сфери складської, митної та налагодженню інформаційної логістики, щоб відповідати зростаючим вимогам підприємств-партнерів.

Треба розуміти, що остаточний вибір партнера $\epsilon$ завершальним етапом аналізу, i саме від успішності його виконання залежать правильний вибір майбутнього контрагента i, відповідно, успіх або неуспіх майбутньої комерційної угоди.

Висновки та перспективи подальших досліджень. Сьогодні, інвестиційна сфера України демонструє одну 3 найвищих за останнє десятиліття динаміку розвитку на фоні поліпшення ділових очікувань та поступового послаблення інвестиційних ризиків. Така позитивна динаміка говорить про значний потенціал українського меблевого ринку сьогодні і в перспективі. Розвиток і диференціація різних сфер життєдіяльності людей, впровадження нових технологій світової меблевої індустрії відкриватимуть нові можливості для виробників вітчизняних меблів $\mathrm{i}$ сприяти утворенню нових «ніш».

Отже, до головних тенденції на меблевому ринку України доцільно віднести:

- активний приплив в меблеву та деревообробну галузь іноземного капіталу;

- зростання імпорту іноземних меблів;

- зростання експорту меблів українського виробництва.

Направленість українського ринку на «завоювання» іноземних ринків, зумовлює необхідність вдосконалення існуючих методів оцінки рівня якості надання міжнародних транспортних операцій, що допомагають менеджменту логістичних підприємств і клієнтам оптимально оцінити ступінь ефективності послуг, рівень задоволення потреб клієнтів, визначити слабкі і сильні місця в рамках даної діяльності, і скорегувати відповідно до цього систему менеджменту i впровадити інновації. При впровадженні запропонованих «допоміжних критеріїв» до вже існуючих критеріїв оцінки міжнародних логістичних посередників, допоможе меблевим підприємствам ретельніше підходить до вибору потенційних «транспортних партнерів» без зайвих зусиль. 


\section{Література}

1. Офіційний сайт Державної служби статистики України [Електронний ресурс]. Режим доступу: http://www.ukrstat.gov.ua

2. Офіційний сайт Державної фіскальної служби України [Електронний ресурс]. Режим доступу: http://sfs.gov.ua/

3. Смирнов I. Г. Логістика у зовнішньоекономічній діяльності // Регулювання зовнішньоекономічної діяльності : навчальний посібник / I. Г. Смирнов, І. Г. Хільчевська / за ред. I. I. Дахна. - Київ, Центр навчальної літератури, 2009. - C. 65-150.

4. Стаханов Д. В. Таможенная логістика / Д. В. Стаханов, В. Н. Стаханов. - М.: ПРИОР, 2001. - 96 с.

5. Огляд ринку меблів в Україні : тенденції розвитку. Rubarb digital [Електронний pecypc]. - Режим доступу: https://rubarbs.com/ua

6. Лямещь B. I. Системній аналіз / В. І. Лямець, А. Д. Тевяшев. - Харків : ХНУРЕ, 2013. -448 c.

7. Стратегічний план експорту для меблевих підприємств України. Українська Асоціація Меблевиків [Електронний ресурс]. - Режим доступу: http://uafm.com.ua.

8. Дорожня карта конкурентоспроможного розвитку української меблевої промисловості. Українська Асоціація Меблевиків : вебсайт. [Електронний ресурс]. - Режим доступу: http://uafm.com.ua.

9. Міщенко І. В. Митна логістика в Україні : поняття та перспективи розвитку / I. В. Міщенко // Митна справа. - 2009. - № 2. C. 26-29.

10. Логистика при экспорте: с чего начать? [Електронний ресурс]. - Режим доступу: www.zammler.com.ua/ru/logistika-pri-nachat.

11. Звіт про діяльність Міністерства економічного розвитку і торгівлі України за 2017 рік. Міністерство економічного розвитку і торгівлі України [Електронний ресурс]. - Режим доступу: http://www.me.gov.ua.

12. Поступове зростання вітчизняних виробників: аналітичний огляд ринку меблів України. PRO CONSULTING Аналітика ринків. Фінансовий консалтинг [Електронний ресурс]. - Режим доступу: https://pro-consulting.ua.

Стаття надійшла

до редакції : 01.05.2019 p.
13. Горяїнов О. М. Логістика / О. М. Горяїнов. - Харків: ХНАМГ, 2009. - 106 с.

\section{References}

1. Official site of the State Statistics Service of Ukraine. Retrieved from: http://www.ukrstat.gov.ua

2. The Official Website of the State Fiscal Service of Ukraine. Retrieved from: http://sfs.gov.ua

3. Smirnov, I. G. \& Khilchevsky, I. G. (2009). Logistics in foreign economic activity. Regulation of economic activity: a manual. Kyiv, 65-150.

4. Stakhanov, D. V. \& Stakhanov, V. N. (2001). This is logistics. Moscow: PRIOR, 96.

5. Overview of the furniture market in Ukraine: trends of development. Rubarb digital: website. Retrieved from: https://rubarbs.com/ua.

6. Lyametz, V. I. \&. Tevyashev, A. D. (2013). System analysis. Introductory course. Kharkiv: KNURE, 448.

7. The strategic export plan for furniture enterprises of Ukraine. Ukrainian Association of Furniture Manufacturers. Retrieved from: http://uafm.com.ua/.

8. Road map of the competitive development of the Ukrainian furniture prom-word. Ukrainian Association of Furniture Manufacturers: Retrieved from: http://uafm.com.ua.

9. Mischenko, I. V. (2009). Customs Logistics in Ukraine: Concept and Prospects of Development. Customs business, 2, 26-29.

10. Logistics at export: where to start? Retrieved from: www.zammler.com.ua/ru/logistikapri-eksporte-s-chego-nachat.

11. Report on the activities of the Ministry of Economic Development and Trade of Ukraine for 2017. Ministry of Economic Development and Trade of Ukraine. Retrieved from: http://www.me.gov.ua.

12. Gradual growth of domestic producers: analytical review of the Ukrainian furniture market. PRO CONSULTING Market Analysis. Financial Consulting. Retrieved from: https://proconsulting.ua/ua.

13. Goryainov, O. M. (2009). Logistics: Cons-pect lectures. Kharkiv: KSAME, 106.

Стаття прийнята

до друку: 26.06.2019 р.

\section{Бібліографічний опис для цитування :}

Кракос Ю. Б. Позиціонування логістичного підприємства на ринку меблів за умов міжнародного співробітництва / Ю. Б. Кракос, А. О. Приходько // Часопис економічних реформ. - 2019. № 2 (34). - C. 16-25. 